\title{
NOTES ON SANITARY CONDITIONS IN SOUTH AFRICA.
}

\author{
THE COLONY OF NATAL. \\ By MATTHEW ß. PRICE, F.R.I.B.A. \\ (Member.)
}

\begin{abstract}
A the present time the general sanitary conclitions in all parts are A very primitive, with the exception of Durban (Port Natal). which alone can boast a suitable drainage system, and even this extends only over a portion of the town.

The water scliemes are more or less primitive, but are being enlarged or re-arrangerl as requirements demand.

An underground system of surface water drainage is to be found only on a small scale at Durban; elsewhere, as in Maritzburg, the general plan is to have open brick channels at the sides of the streets. These discharge into barrel clrains at certain positions, but the large volume of water in heary storms is far too great for the present outlets, and the roads become completely flooded in a very short space of time, and frequently the small wood bridges forming cartways over these gutters are carried away.
\end{abstract}

In Durban, where there are soil drains, long lengths of channel drains for surface water only are of little objection, but in Pietermaritzburg, where there are no soil drains, and all the surface drainage from the houses also discharge into these open channels, including bath water, slops, etc., it will be at once evident that at all times effuvia are being evolved into the main thoroughfares, and this state of things, after a long drought, and in such a warm climate, is not only very offensive, but has no doubt a bad effect upon the public health, and probably has much to do with the diseases so prevalent, such as enteric, dysentery, and low fevers. Strange to say, however, notwithstanding this circumstance the death-rate is remarkably low.

As regards altitude, death-rate, and general conditions of various towns, I will briefly touch upon each under their several headings.

A serious difficulty to be overcome in all parts of South Africa is the VOL. XXIII. PART III. 


\section{Notes on Sanitary Conditions in South Africa.-Natal.}

uncleanly habits of the coloured population, which in Natal stands to the white in the proportion of about ten to one, and until constant and strict superrision is maintained insanitary conditions, as regards their dwellings generally, will continue.

Ventilation in the more modern work is invariably and amply provided, and in all Government work it is carefully considered. Fanlights and numerous air gratings are to be found even in the smallest cottages. Artificial heat being but little used, and gas practically unknown, there is comparatively slight difficulty in dealing with the matter here.

The Colony of Natal is situated about 818 miles from the Cape of Good Hope, 350 from Algoa Bay, 253 from East London, and 126 from St. John's River. It comprises about 21,150 square miles, and is bounded on the North by Swaziland; South by Pondoland and East Griqualand; East by Indian Ocean; West by Basutoland, the Orange Rirer Colony, and the Vaal River Colony.

In the central county the thirtieth degree of south latitude and the thirtieth degree of east longitude cross each. There is a seaboard of about 180 miles. The population consists of Europeans, Natives, and Indians. The last census was being taken in 1901, but owing to war being declared it was never completed, and no reliable information is obtainable at present.

\section{Durban (Port Natal)}

Is situated just above the sea level, being $29^{\circ} 50^{\prime} 48^{\prime \prime}$ Suuth latitude, and $30^{\circ} 4^{\prime} 1^{\prime \prime}$ East longitule. The death-rate is about 16 to 17 per 1000 .

The consumption of water in Durban is three-and-a-half million gallons per diem, and the population 60,000. There are two sources of supply; the higher level service from the Umbilo River, and the lower level, from the Umlaas River. From the high level supply approximately 200,000 gallons per diem are drawn, the rest being supplied from the low level, the Umlaas.

The chief works consist of a storage reservoir at Camperdown, some 50 miles from Durban. which will have a capacity of five hundrecl million gallons. At the lower section of the works, 12 miles distant from Durban, there is in course of construction a clear-water storage reservir, which will have a capacity of one hundred and twenty million gallons, and sand filtering beds capable of dealing efficiently with four million gallons per diem. From the intake to the site of the clear-water storage reservoir there are over $1 \frac{1}{2}$ miles of tumnels, and 4 miles of conduits and siphons. The whole length of the cast iron and steel supply mains, and distribution mains, exceeds 120 miles. 
At the Umbilo Works there is a storage reserroir of thirty five million gallons capacity. There are service reserroirs within the Borough area of supply of a total capacity of eight-and-a-half million gallons.

The sewerage works deal with the area which practically takes in the whole of the town proper; and extensions are being made to the suburban districts. The total length of mains laid is close on 40 miles, and art additional 40 miles are now in hand. The main outfall is 42 inches in diameter. The sewage is pumped to a height of 24 feet, double screened, and stored in a tank ready for discharging into the Bluff channel at the head of each tide. The whole scheme is one of gravitation to the main pumping station at the outfall works, but, as the districts are extendecl, some of the low lying lands will necessitate the raising of the sewage from limited areas which will be done on the Shone's pneumatic system.

\section{Miritzbura}

Is the capital of the Colony of Natal. Situation, about S. latitude $29^{\circ}$ $36^{\prime} 0^{\prime \prime}$, East longitude $30^{\circ} 24^{\prime} 0^{\prime \prime}$. The Native name is Ungungunhlovu, which means the "Place of the Great White Elephnut," viz., Seat of Government. Elevation 2,218 feet above the sea level. The death-rate is about $12 \cdot 7$ per 1,000 . Soil disposal, buckets.

The existing sanitary conditions in Maritzburg are of the most primitive nature, and there is nothing approaching to a system for dealing with either trade or domestic sewage.

A storm water drainage scheme was introduced here some six or seven years ago, but only partially completed, and at present the storm water underground drains, which cover about one-sixth of the street area of the city, are used as sewers. All sewage, except that from the Brewery, and the contents of the night soil pails, is discharged into open brick drains adjoining the buildings, and thence into the street gutters, on to catchpits, some of which have been trapped, and from here the sewage enters the underground storm-water drains and flows into the Umsinclusi River, which bounds the city on the south side, and the Dorp Spruit, which bounds the city on the north side. These drains are a source not only of annoyance, bnt of grave public danger to the whole community.

The water supply is so low during the winter months that very little can be spared for the purpose of flushing, so that these drains, wherever the gradients are flat, continually give off foul gases from the decomposing matter lying on the invert. Occasional flushing takes place, but this is only on a minor scale. The usual custom prevailing here is to wait for the first summer rains, when Nature cleanses the sewers herself. This, 
practically, means that for six months in the year the whole filth of the town finds its way into these drains, and remains there until discharged by the flushing process indicated.

The Council, however, are making every effort to carry out improvements in this city, and first and foremost among the municipal reforms now being undertaken is that of a water supply. A sum of $£ 175,000$ is being spent for this purpose, and it is hoped that when the present scheme is completed, about the beginning of the year 1904, that an adequate supply of water will be available. The scheme has been designed to deliver seventy gallons of water per head per diem, and provision is also being made to ultimately provide for a population of 300,000 inhabitants on this basis.

The water supply then being assured, the Council have next devoted their attention to the question of sewerage, and a scheme is now in course of preparation. Presumably the process of treatment will be on the identical lines with that of Manchester. Double contact beds, however, will be used for the present, a third set being added later, if required, a period of rest being allowed in the aerobic beds of four hours to six hours.

The approximate cost of a Sewerage Scheme for this city would be $£ 170,000$. $£ 125,000$ of this sum could be paid out of the moneys at present expended on the night-soil system, the remaining amount would have to be met by a special rate, but this would be a trifling sum of something like an eighth-of-a-penny in the pound, and no one would be found to grumble at so small an amount when the advantages of a good sewerage scheme are understood and appreciated by the public.

Stoneware pipes will be used wherever possible. Most of the material in which the sewers will be laid is shale. The outfall sewer, which will be through whinstone, will be dressed to the correct invert and rendered in cement. The gravity system, it is hoped, will be obtained throughout. The scheme should be put in hand early next year, if adopted by the Council.

\section{NewCASTLE.}

Elevation, 3,892 feet above the sea-level. Death-rate, $35 \cdot 7$; high rate due to military. Soil disposal, buckets. Water system, drawn from springs, supplied by means of pipes. The coal industry is carried on in the district.

\section{DUNDEE.}

Elevation, 4,100 feet above the sea-level. Death-rate, 29.5 ; high rate due to military. Soil disposal, buckets. Water system drawn from springs, and supplied by means of pipes. Centre of coal district. 


\section{LADYSMTTH.}

Elevation, 3,285 feet above the sea-level. Death-rate, $8 \cdot 8$, since removal of the military hospitals. Soil disposal, buckets. Water system, drawn from the Klip River, and supplied by means of pipes.

\section{Greytown.}

Elevation, 3,581 feet above the sea-level. Death-rate, $15 \cdot 0$. Soil disposal, buckets. Water system, supplied by pipes.

\section{Estcourt.}

Elevation, 3,833 feet above the sea-level. Soil clisposal, buckets. Water system, supplied by pipes.

\section{Howrok.}

Elevation, 3,439 feet above the sea-level. Soil disposal, buckets. Water system, supplied by pipes.

\section{RICHMOND.}

Elevation, 3,439 feet above the sea-level. Soil disposal, buckets. Water system, supplied by pipes.

\section{Ixopo.}

Elevation, 3,439 feet above the sea-level. Soil disposal, buckets. Water system, supplied by pipes.

Umzinto. Stanger. Port Shepstone. Eshowe.

Obtain water from streams by buckets or carts, and use rain-water storage tanks. There is no organised sanitary service.

\section{VERULAM.}

Obtains water from streams by buckets or carts, and uses rain-water storage tanks. There is no organised sanitary service. Death-rate, $25 \cdot 3$, due to large Indian population working on sugar estates.

In conclusion, I would draw your attention to the fact that the last recorded death-rate inclucles refugees and aliens beyond normal population, and so is necessarily heavier than the average, but it is only this year that general statistics have been compiled.

Enteric fever, which played such havoc with our troops, may be attributed largely to insanitary conditions which, under the circumstances, were unavoidable, and deaths reported from this cause should show a great decrease as proper sanitary arrangements are introduced. 